\title{
Actual survival after resection of primary colorectal cancer: results from a prospective multicenter study
}

Inge van den Berg ${ }^{*}$ (D, Robert R. J. Coebergh van den Braak, Jeroen L. A. van Vugt, Jan N. M. ljzermans and Stefan Buettner

\begin{abstract}
Background: Colorectal cancer is the third most common type of cancer in the world. We characterize a cohort of patients who survived up to 5 years without recurrence and identify factors predicting the probability of cure.

Methods: We analyzed data of patients who underwent curative intent surgery for stage I-III CRC between 2007 and 2012 and who had had been included in a large multicenter study in the Netherlands. Cure was defined as 5year survival without recurrence. Survival data were retrieved from a national registry.

Results: Analysis of data of 754 patients revealed a cure rate of $65 \%(n=490)$. Patients with stage I disease and T1and N0-tumor had the highest probability of cure (94\%, 95\% and $90 \%$, respectively). Those with a T4-tumor or N2tumor had the lowest probability of cure $(62 \%$ and $50 \%$, respectively). A peak in the mortality rate for older patients early in follow-up suggests early excess mortality as an explanation. Patients with stage III disease, poor tumor grade, postoperative complications, sarcopenia and R1 resections show a similar trend for decrease in CSS deaths over time.

Conclusion: In the studied cohort, the probability of cure for patients with stage I-III CRC ranged from 50 to 95\%. Even though most patients will be cured from CRC with standard therapy, standard therapy is insufficient for those with poor prognostic factors, such as high $\mathrm{T}$ - and $\mathrm{N}$-stage and poor differentiation grade.
\end{abstract}

\section{Introduction}

With an incidence of over 1.8 million new cases and almost 861,000 deaths in 2018 according to the World Health Organization, colorectal cancer (CRC) is the third most common cancer in the world [1]. Currently, the American Joint Committee on Cancer (AJCC) TNM classification is the most important determinant for treatment decisions and outcome. The standard treatment for stage I-III colon cancer is surgical resection of the primary tumor for patients,

\footnotetext{
* Correspondence: i.vandenBerg@erasmusmc.nl
}

Department of Surgery, Erasmus MC - University Medical Center Rotterdam, Rotterdam 3015 GD, The Netherlands which is associated with a 5 -year survival rate ranging from $92 \%$ in stage 1 to $53 \%$ in stage III [2]. Still, clinical outcomes of individual patients with resectable tumors vary. Besides tumor characteristics, patient factors such as obesity, diabetes mellitus, smoking, and nutritional status have been associated with survival, yet much of the disparity in prognosis remains unexplained [3-5].

Recurrence of CRC is chiefly a time-limited phenomenon, as $60-80 \%$ of recurrences becoming apparent within the first 2 years after resection and $95 \%$ within the first 4 years after resection [6]. The chances of recurrence remote after a 5-year recurrence-free period. Although recurrence is still possible after 5 years, the medical community considers many cancers "cured"

(c) The Author(s). 2021, corrected publication May 2021. Open Access This article is licensed under a Creative Commons Attribution 4.0 International License, which permits use, sharing, adaptation, distribution and reproduction in any medium or format, as long as you give appropriate credit to the original author(s) and the source, provide a link to the Creative Commons licence, and indicate if changes were made. The images or other third party material in this article are included in the article's Creative Commons licence, unless indicated otherwise in a credit line to the material. If material is not included in the article's Creative Commons licence and your intended use is not permitted by statutory regulation or exceeds the permitted use, you will need to obtain permission directly from the copyright holder. To view a copy of this licence, visit http://creativecommons.org/licenses/by/4.0/. The Creative Commons Public Domain Dedication waiver (http:// creativecommons.org/publicdomain/zero/1.0/) applies to the data made available in this article, unless otherwise stated in a credit line to the data. 
when recurrence has not occurred within 5 years after diagnosis [7]. Owing to the considerable progress in the treatment in CRC during the past few decades, more and more patients remain free from recurrent disease after surgery $[8,9]$. Even though the ideal intensity of follow-up is being debated $[10,11]$, the recurrence rate has been shown to reach a plateau phase 5 years after resection of the primary tumor. This is why follow-up programs in the Netherlands and many other countries have been limited to 5 years $[10,12-14]$. In this multicenter study in a large Dutch colorectal cancer population, we sought to characterize the patients who survive up to 5 years without recurrence of disease and identify factors that affect probability of cure.

\section{Methods}

\section{Study population}

We analyzed data of patients with stage I-III colorectal cancer who had undergone curative intent surgery and had between 2007 and 2012 been enrolled in the MATC $\mathrm{H}$-study, a prospective observational cohort study in patients undergoing curative resection for primary colorectal cancer in seven centers in the region of Rotterdam, the Netherlands [15]. The purpose of the MATCH study was to identify subtypes of colorectal cancer, related prognostic markers and outcome of treatment [16]. The MATCH study was approved by the Erasmus MC medical ethics review board (MEC-2007-088), and all patients provided written informed consent. All patients enrolled between 2007 and 2012 had the potential for 5 years of follow-up.

\section{Patient work-up and follow-up Work-up}

All patients underwent colonoscopy with a biopsy of any suspicious lesions. After tissue diagnosis was confirmed, laboratory studies were done with a goal of assessing patients' organ function (liver, kidneys) in anticipation of diagnostic and therapeutic procedures and also to estimate tumor burden. Adequate imaging of the chest and abdomen was obtained for staging purposes. For colon cancer patients, this consisted of CT-abdomen and Xthorax and ultrasound of the liver when indicated. For rectal cancer patients, this consists of CT-thorax/abdomen and MRI rectum/pelvis.

Further work-up was driven by clinical setting, patient functional status and comorbidities and presenting symptoms. After adequate staging, adjuvant chemotherapy was offered for patients with high risk stage II and stage III colon cancer. At the time of this study, standard treatment consisted of 6 months CAPOX or FOLFOX. For rectal cancer patients, preoperative radiotherapy was offered for patients with T2-T4 tumors. For rectal cancer patients with positive CRM, or $\geq 4$ positive lymph nodes, a combination of neoadjuvant radiotherapy and chemotherapy was offered.

\section{Follow-up}

CEA monitoring was performed 3-to-6 monthly in the first 3 years and 6-to- 12 monthly hereafter and ultrasound of the liver or an abdominal CT every 6 months in the first 1-2 years and yearly hereafter. For rectal cancer patients, an additional $\mathrm{x}$-thorax or CT-thorax could be considered, depending on the stage.

\section{Observed cure and follow-up status}

Observed cure was defined as actual 5-year survival with no recurrence $[6,7,13,14]$. At last follow-up, a patient was classified as having no evidence of disease (NED) if having survived without documented recurrence and as having died of disease (DOD) if the cause of death was listed as cancer in the national death registry. A patient classified as death of other cause (DOC) if a clearly attributable non-cancer reason for death was mentioned in the registry of Statistics Netherlands (Centraal Bureau voor de Statistiek; CBS). A patient was classified as dead of unknown cause (DUC) if no identifiable cause of death was found in the registry of Statistics Netherlands. A 5-year survivor with evidence of recurrent disease in the medical record was classified as alive with disease (AWD) [17].

\section{Predictors and outcome measures}

Demographic variables included age and gender. Clinical variables included BMI, American Society of Anesthesiologists (ASA) score, International Union Against Cancer tumor node metastasis (TNM) classification of malignant tumors, tumor differentiation grade, tumor location, comorbidities, Charlson comorbidity index, and sarcopenia [18]. Treatment variables included the following: radicality, (neo)adjuvant therapy, postoperative complications classified according to Clavien-Dindo, and readmissions $<30$ days.

To identify characteristics that may preclude longterm survival and cure, we compared the frequencies of these factors between specific survival cohorts defined as less than 1,1 to 3,3 to 5 , and more than 5 years [17].

Cancer-specific survival (CSS) was calculated from the day of surgery to the day of death (from disease) or loss to follow-up, whichever came first. Date and cause of death were obtained from the national registry of Statistics Netherlands (Centraal Bureau voor de Statistiek; CBS). Patients who died of other causes than CRC were censored at the date of last follow-up. CSS was estimated using Kaplan-Meier methods and compared using log-rank. 


\section{Statistical methods}

The standard Cox proportional hazard model assumes proportional hazards, an assumption that can fail when survival curves have plateaus at the tails [19]. Hence, a semi-parametric proportional hazards mixture cure model was used to estimate the probability of cure and assess differences in outcome between cured patients and those who were not cured. In this model, the probability of being cured was modeled with logistic regression and the survival probability for patients who experienced the event of interest was estimated using a proportional hazards model [20-22]. All analyses were performed using the smcure package in R. v.3.3.2 ( $\mathrm{R}$ foundation for Statistical Computing, Vienna, Austria) [22]. Two-sided $p$ values $<$ 0.05 were considered statistically significant.

\section{Results}

Patient characteristics and follow-up status

A total of 754 patients included in the MATCH study underwent surgical resection with curative intent in the period 2007 through 2012 (Fig. 1). At last follow-up, 117 patients (15.2\%) could be classified as DOD, 40 (5.3\%) as AWD, and $11(1.5 \%)$ as AUD. In total, 93 patients (12.3\%) could be classified as DOC and 29 (3.8\%) as DUC. Data of the latter were excluded from CSS analyses. After 5 years of follow-up, 464 patients (61.5\%) could be classified as NED and 26 (3.4\%) died of a noncancer related cause (DOC). These patients are considered cured from disease (NED + DOC $>5 \mathrm{Y} ; n=$ 490) (Fig. 1).

\section{Cancer-specific survival through follow-up}

Table 1 reports descriptive analyses on characteristics of patients over time. Patients were grouped by survival into less than 1 year survival, $1-3$ years, 3-5 years, more than 5-years survival, and an additional category cured. The first three groups include only DOD patients; the non-cured group $>5$ years consists of AWD, DOD, and AUC patients. The cured patients included $52.2 \%$ men, and $42.9 \%$ were aged $\geq$ 70. The latter relatively more often had died of CRC in the early years following surgery than had patients $<70$ years, as can be seen in Table 1 from the decreasing proportion of older aged patients dying of CRC over time and increasing proportions of younger patients dying over time. Patients with stage III colon cancer, poor tumor grade, postoperative complications, sarcopenia, and or an incomplete resection margin show a similar trend for decrease in CSS deaths over time (Table 1).

Kaplan-Meier survival analyses were performed to determine which characteristics were associated with CSS. It appeared that age $>70(p<0.001)$, preoperative CEA level $\geq$ $7 \mu \mathrm{g} / \mathrm{L}(p=0.001)$, high T-stage $(p<0.001)$, high $\mathrm{N}$-stage $(p<0.001)$, high tumor stage $(p<0.001)$, poor tumor differentiation $(p=0.010)$, rectal cancer $(p=0.039)$, and occurrence of postoperative complications $(p=0.039)$ were all

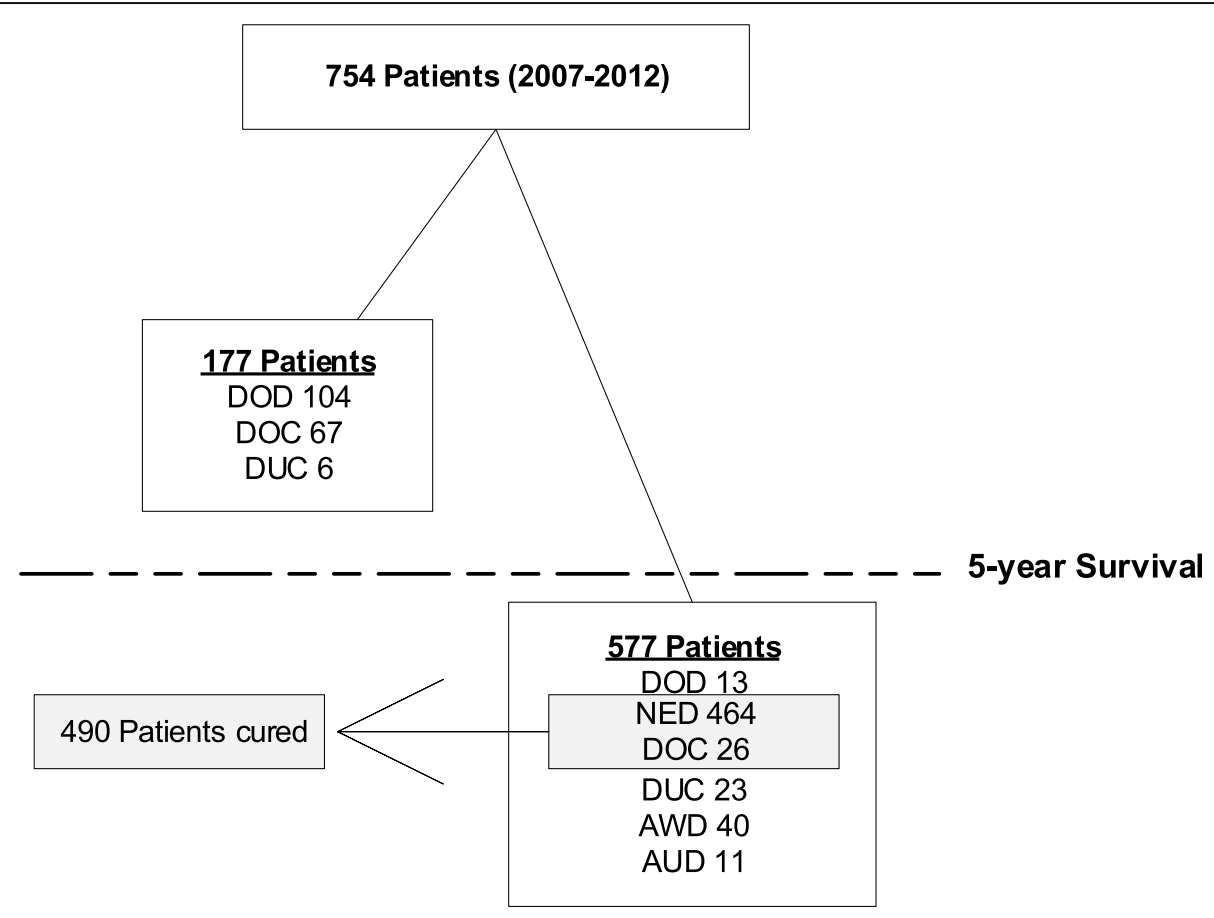

Fig. 1 Current status and observed cure in study population 
Table 1 Comparison of prognostic factors among survival cohorts

\begin{tabular}{|c|c|c|c|c|c|c|c|c|c|c|c|}
\hline & $0-1$ & $\%$ & $1-3$ & $\%$ & $3-5$ & $\%$ & $>5^{\mathrm{a}}$ & $\%$ & Cured & $\%$ & Missing $\%$ \\
\hline Gender & & & & & & & & & & & 0 \\
\hline Male & 18 & $(64.3)$ & 31 & (63.3) & 13 & $(48.1)$ & 34 & (53.1) & 256 & $(52.2)$ & \\
\hline Female & 10 & $(35.7)$ & 18 & $(36.7)$ & 14 & (51.9) & 30 & $(46.9)$ & 234 & $(47.8)$ & \\
\hline Age & & & & & & & & & & & 0 \\
\hline$<70$ & 5 & $(17.9)$ & 17 & (34.7) & 11 & $(40.7)$ & 31 & $(48.4)$ & 280 & $(57.1)$ & \\
\hline$\geq 70$ & 23 & (82.1) & 32 & (65.3) & 16 & $(59.3)$ & 33 & (51.6) & 210 & $(42.9$ & \\
\hline BMI & & & & & & & & & & & 1.1 \\
\hline $1(<18.5)$ & 1 & (3.7) & 1 & (2.0) & 1 & (3.7) & 0 & $(0.0)$ & 15 & (3.1) & \\
\hline $2(18.5-24.9)$ & 10 & $(37.0)$ & 22 & (44.9) & 10 & (37.) & 20 & (32.3) & 181 & $(37.3)$ & \\
\hline $3(\geq 25.0)$ & 16 & $(59.3)$ & 26 & (53.1) & 16 & $(59.3)$ & 42 & $(67.7)$ & 289 & (59.6) & \\
\hline Sarcopenia & & & & & & & & & & & 18.8 \\
\hline No & 7 & $(31.8)$ & 15 & $(41.7)$ & 10 & $(47.6)$ & 23 & $(50.0)$ & 211 & $(51.8)$ & \\
\hline Yes & 15 & $(68.2)$ & 21 & $(58.3)$ & 11 & $(52.4)$ & 23 & $(50.0)$ & 196 & $(48.2)$ & \\
\hline Low muscle density & & & & & & & & & & & 19.6 \\
\hline No & 5 & (23.8) & 11 & $(40.6)$ & 6 & (28.6) & 13 & $(29.5)$ & 159 & $(39.4)$ & \\
\hline Yes & 17 & $(76.2)$ & 25 & $(69.4)$ & 15 & $(71.4)$ & 31 & (70.5) & 245 & $(60.6)$ & \\
\hline Sarcopenia + obese & & & & & & & & & & & 0 \\
\hline No & 26 & $(92.9)$ & 44 & (89.8) & 26 & $(96.3)$ & 63 & $(98.4)$ & 465 & (94.9) & \\
\hline Yes & 2 & (7.1) & 5 & $(10.2)$ & 1 & (3.7) & 1 & (1.6) & 25 & $(5.1)$ & \\
\hline Diabetes mellitus & & & & & & & & & & & 0.1 \\
\hline No & 22 & (78.6) & 41 & $(83.7)$ & 20 & (76.9) & 48 & $(75.0)$ & 402 & $(82.0)$ & \\
\hline Yes & 6 & $(21.4)$ & 8 & $(16.3)$ & 6 & $(23.1)$ & 16 & $(25.0)$ & 88 & $(18.0)$ & \\
\hline Congestive heart failure & & & & & & & & & & & 0 \\
\hline No & 25 & $(89.3)$ & 45 & $(91.8)$ & 24 & $(88.9)$ & 63 & $(98.3)$ & 466 & $(95.1)$ & \\
\hline Yes & 3 & $(10.7)$ & 4 & $(8.2)$ & 3 & $(11.1)$ & 1 & (1.6) & 24 & (4.9) & \\
\hline COPD & & & & & & & & & & & 0 \\
\hline No & 27 & $(96.4)$ & 44 & $(89.8)$ & 23 & $(85.2)$ & 62 & $(96.9)$ & 454 & $(92.7)$ & \\
\hline Yes & 1 & (3.6) & 5 & $(10.2)$ & 4 & $(14.8)$ & 2 & (3.1) & 26 & (7.3) & \\
\hline Charlson comorbidity index & & & & & & & & & & & 0.4 \\
\hline 0 & 11 & $(39.3)$ & 23 & $(46.9)$ & 10 & $(38.5)$ & 39 & $(60.9)$ & 266 & $(54.4)$ & \\
\hline $1+$ & 17 & $(60.7)$ & 26 & $(53.1)$ & 16 & $(61.5)$ & 25 & $(39.1)$ & 223 & $(45.6)$ & \\
\hline \multicolumn{12}{|l|}{ ASA score } \\
\hline$|-| \mid$ & 22 & (78.6) & 45 & $(91.8)$ & 20 & $(74.1)$ & 54 & $(85.7)$ & 409 & $(84.2)$ & \\
\hline||$|-| V$ & 6 & $(21.4)$ & 4 & (8.2) & 7 & $(25.9)$ & 9 & $(14.3)$ & 77 & $(15.8)$ & \\
\hline CEA & & & & & & & & & & & 8.6 \\
\hline$<7 \mu \mathrm{g} / \mathrm{L}$ & 21 & $(90.8)$ & 28 & (59.6) & 11 & $(45.8)$ & 36 & (62.1) & 360 & (79.5) & \\
\hline$\geq 7 \mu \mathrm{g} / \mathrm{L}$ & 5 & $(19.2)$ & 19 & $(40.4)$ & 13 & $(54.2)$ & 22 & (37.9) & 93 & (20.5) & \\
\hline \multicolumn{12}{|l|}{ Tumor location } \\
\hline Colon & 20 & $(71.4)$ & 31 & $(63.3)$ & 14 & $(51.9)$ & 41 & (64.1) & 371 & $(75.7)$ & 0 \\
\hline Rectum & 8 & (28.6) & 18 & $(36.7)$ & 13 & $(48.1)$ & 23 & (35.9) & 119 & $(24.3)$ & \\
\hline T-stage & & & & & & & & & & & 0 \\
\hline 1 & 2 & (7.1) & 0 & & 1 & (3.7) & 2 & (3.1) & 34 & (6.9) & \\
\hline 2 & 7 & (25) & 5 & $(10.2)$ & 7 & $(25.9)$ & 22 & (34.3) & 171 & (34.9) & \\
\hline 3 & 16 & $(57.1)$ & 38 & $(77.6)$ & 17 & (63) & 36 & $(56.2)$ & 270 & $(55.1)$ & \\
\hline 4 & 3 & (10.7) & 6 & $(12.2)$ & 2 & (7.4) & 4 & (6.2) & 15 & (3.1) & \\
\hline
\end{tabular}


Table 1 Comparison of prognostic factors among survival cohorts (Continued)

\begin{tabular}{|c|c|c|c|c|c|c|c|c|c|c|c|}
\hline & $0-1$ & $\%$ & $1-3$ & $\%$ & $3-5$ & $\%$ & $>5^{a}$ & $\%$ & Cured & $\%$ & Missing $\%$ \\
\hline N-stage & & & & & & & & & & & 0 \\
\hline 0 & 8 & (28.6) & 13 & (26.5) & 6 & $(22.2)$ & 36 & $(56.2)$ & 303 & (61.8) & \\
\hline 1 & 5 & (17.9) & 10 & (20.4) & 7 & (25.9) & 11 & $(17.2)$ & 103 & (21) & \\
\hline 2 & 12 & $(42.9)$ & 21 & $(42.9)$ & 7 & (25.9) & 7 & (25.9) & 33 & (6.7) & \\
\hline$x$ & 3 & $(10.7)$ & 5 & (10.4) & 7 & (25.9) & 10 & (15.6) & 51 & (10.4) & \\
\hline Tumor stage & & & & & & & & & & & 0 \\
\hline I & 7 & (25.0) & 4 & $(8.2)$ & 5 & $(18.5)$ & 22 & (34.4) & 164 & (33.5) & \\
\hline$\|$ & 4 & (14.3) & 14 & (28.6) & 8 & (29.6) & 24 & (37.5) & 190 & (38.8) & \\
\hline III & 17 & $(60.7)$ & 31 & (63.3) & 14 & (51.9) & 18 & (28.1) & 136 & (27.8) & \\
\hline Tumor grade & & & & & & & & & & & 1.5 \\
\hline Good & 1 & (3.7) & 5 & (10.4) & 3 & (11.1) & 10 & (15.9) & 66 & (13.7) & \\
\hline Moderate & 16 & (59.3) & 36 & (75.0) & 21 & $(77.8)$ & 47 & $(74.6)$ & 377 & (78.1) & \\
\hline Poor & 8 & (29.6) & 7 & (14.6) & 3 & (11.1) & 5 & (7.9) & 33 & (6.8) & \\
\hline Unknown/other & 2 & (7.4) & 0 & & 0 & & 1 & (1.6) & 7 & (1.4) & \\
\hline Radicality & & & & & & & & & & & 0.3 \\
\hline RO & 26 & (92.6) & 48 & $(98.0)$ & 27 & $(100.0)$ & 63 & (98.4) & 477 & $(97.5)$ & \\
\hline R1 & 2 & (7.1) & 1 & (2.0) & 0 & & 1 & (1.6) & 12 & (2.5) & \\
\hline Postoperative complications & & & & & & & & & & & 0 \\
\hline No & 6 & (21.4) & 24 & $(49.0)$ & 8 & (29.6) & 38 & $(59.4)$ & 298 & $(60.8)$ & \\
\hline Yes & 22 & (78.6) & 25 & (51.) & 19 & $(70.4)$ & 26 & (40.6) & 193 & $(39.2)$ & \\
\hline Readmission $<30$ days & & & & & & & & & & & 0.1 \\
\hline No & 24 & $(88.9)$ & 47 & (95.9) & 23 & $(85.2)$ & 55 & $(85.9)$ & 438 & $(89.4)$ & \\
\hline Yes & 3 & $(11.1)$ & 2 & (4.1) & 4 & $(14.8)$ & 9 & $(14.1)$ & 52 & (10.6) & \\
\hline Neoadjuvant chemotherapy & & & & & & & & & & & 0 \\
\hline No & 20 & (71.4) & 33 & $(59.3)$ & 16 & $(59.3)$ & 43 & $(67.2)$ & 383 & $(78.3)$ & \\
\hline Yes & 8 & (28.6) & 16 & $(32.7)$ & 11 & $(40.7)$ & 21 & (32.8) & 106 & (21.7) & \\
\hline Adjuvant chemotherapy & & & & & & & & & & & 0 \\
\hline No & 28 & $(100)$ & 37 & $(77.1)$ & 22 & $(81.5)$ & 55 & $(85.9)$ & 382 & (78.6) & \\
\hline Yes & 0 & & 11 & (22.9) & 5 & (18.5) & 9 & $(14.1)$ & 104 & $(21.4)$ & \\
\hline
\end{tabular}

${ }^{\mathrm{a} N o n-c u r e d}$ group $>5$ years consists of AWD, DOD, and AUC patients

significantly associated with shorter CSS (Table 1; Fig. 2). It should be noted that from the patients with an N0 tumor, a total of 85 patients had $<10$ lymph nodes dissected which could have led to wrong nodal staging.

\section{Observed cure and predicted cure}

The potential survival cohort in Table 2 includes the 621 patients categorized as NED, DOD, or AWD. Overall, 577 patients survived 5 years. Most of them had been classified as NED $(n=464,80.4 \%)$ and a small minority ( $n=26,4.5 \%)$ as DOC. These two groups are considered cured from disease; thus, the observed cure rate was $65 \%$ (490/754). At 5 years follow-up, 40 patients were classified as AWD and 13 as DOD. Data on recurrence were missing for 11 patients alive at 5 years (AUD). The CSS for the whole study cohort is visualized by a Kaplan-Meier curve (Fig. 3).
The observed cure rate in patients aged $\geq 70$ years was $74.7 \%$, versus $82.3 \%$ for patients aged $<70$ years. The observed cure rate for women was slightly higher than that for men $(81.8 \%$ versus $76.4 \%)$. The observed cure rate for patients with a T4-tumor was notably low at $50 \%$ and considerably higher for patients with a T1tumor (94.4\%), T2-tumor (88.6\%), and even those with a T3-tumor (75.6\%). Patients with a N2-tumor had the lowest observed cure rate, viz. only $41.3 \%$, as opposed to $90.2 \%$ for patients with N0-tumor and $76.9 \%$ for patients with an N1-tumor. The observed cure rate for patients with stage III CRC was $63.6 \%$, almost $30 \%$ lower than that for patients with stage I disease (91.1\%). Furthermore, the observed cure rate for patients with a poor tumor grade was only $62 \%$-in line with that for patients with CEA $\geq 7 \mu \mathrm{g} / \mathrm{L}$ (64\%) and patients with rectal cancer (67\%). 


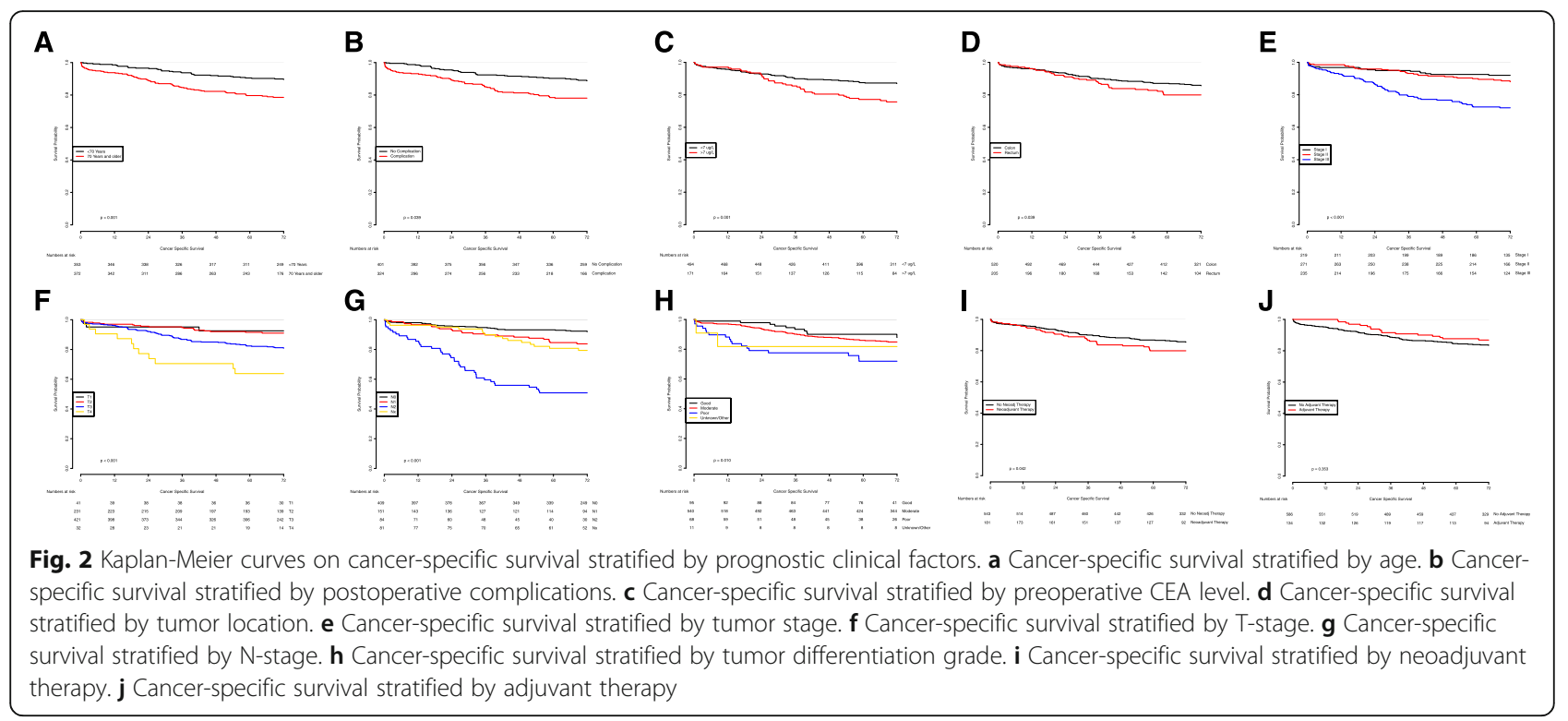

The predicted cure rate of $80.1 \%$ for patients $\geq 70$ years of age is slightly higher than the observed cure rate for this group (Table 2). Patients with a T1- and/or N0tumor had the highest probability of cure, i.e., $94.4 \%$ and $90.2 \%$, respectively. Conversely, patients with a T4tumor or N2-tumor had the lowest probability of cure, i.e., $62.3 \%$ and $50.1 \%$, respectively. The predicted probability of cure for tumor stage was $94 \%$ for stage I, $88 \%$ for stage II, and $71 \%$ for stage III. Regarding type of cancer, colon cancer was associated with a higher probability of cure than is rectal cancer $(85.5 \%$ versus $80 \%)$. Two other factors were associated with a relatively low probability of cure, i.e., preoperative CEA level of $>7 \mathrm{uq} / \mathrm{L}$ and poor tumor differentiation (both $73 \%$ ). The predicted cure rate of patients who experienced postoperative complications was $76.8 \%$. Although underweight BMI and diabetes were not significantly associated with CSS in univariate analyses, both had a relatively low probability of cure in the mixture cure model $(75.6 \%$ and $73.1 \%$, respectively). Nonetheless, patients who did not have postoperative complications and had not been readmitted within $<30$ days postoperatively had a probability of cure of over $90 \% \quad(90.4 \%$ and $94.1 \%$, respectively).

\section{Discussion}

The findings of this multicenter cohort study are consistent with failure of the curative intent treatment strategies for stage I-III CRC in 35\% of cases. Age > 70 years at diagnosis, high preoperative CEA level, rectal cancer, high $\mathrm{T}$-and $\mathrm{N}$-stage, high tumor stage, poor tumor differentiation, and postoperative complications were all individual poor prognostic factors for cancer-specific survival after surgery for stage I-III CRC. Observations and mixture cure model analysis showed that patients with T4-stage, N2-stage, stage III CRC, CEA level $\geq$ $7 \mu \mathrm{g} / \mathrm{L}$, and poor tumor differentiation had the lowest chance of eventual cure. Nevertheless, the clear majority of 5-year survivors (65\%) had no evidence of disease or had died of a non-cancer related cause and could therefore be defined as cured. Patients with a T1-stage tumor, N0-stage tumor, tumor stage I, and/or postoperative complications had the highest probability of cure (> 90\%).

In the Netherlands and most other countries, once a patient has remained free from recurrence of disease for 5 years after surgery, the medical community considers many cancers "cured" [7]. Although recurrence of disease after 5 years is not impossible, the probability of this happening is very low. Therefore, follow-up programs are usually limited to 5 year postoperatively $[10,12]$.

We found that the pathologic tumor characteristics were the most important indicators of probability of cure. The probability of cure for patients with a T1tumor was $92 \%$, which decreased to $62 \%$ for patients with a T4-tumor. Correspondingly, the probability of cure for patients with an N0-tumor was 93\%, which decreased markedly to $50 \%$ for patients with an N2-tumor. These findings are in line with previous research by Gunderson and colleagues, who showed a 5-year survival rate of $97 \%$ for both patients with a T1N0 tumor and patients with T2N0 tumor, compared with 55\% for patients with a T4N0 tumor and $56.8 \%$ for patients with a T1N2 tumor [23]. Tumor grade is generally considered a stage-independent prognostic factor for survival, in that poor differentiated tumors are associated with poor patient survival $[24,25]$. In the current study, poorly differentiated tumors were associated with a significantly 
Table 2 Characteristics of patients with potential cure and probability of cure estimated from the semiparametric mixture cure model

\begin{tabular}{llll}
\hline Total NED, DOD, & Observed $\%$ & Predicted \\
AWD $(N=621)$ & $\begin{array}{l}5 \text {-year } \\
\text { survivors }\end{array}$ & observed & cure \\
& & \\
\hline
\end{tabular}

\section{Gender}

Male $\quad 335$

Female $\quad 286$

Age

$\begin{array}{ll}<70 & 340 \\ \geq 70 & 281\end{array}$

BMI

$$
\begin{array}{ll}
1(<18.5) & 17 \\
2(18.5- & 228 \\
24.9) & \\
3(\geq 25.0) & 368
\end{array}
$$

Sarcopenia

$\begin{array}{ll}\text { No } & 254 \\ \text { Yes } & 246\end{array}$

Low muscle density

$\begin{array}{ll}\text { No } & 190 \\ \text { Yes } & 305\end{array}$

Sarcopenia + obesity

$\begin{array}{ll}\text { No } & 590 \\ \text { Yes } & 31\end{array}$

Diabetes mellitus

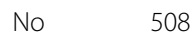

Yes $\quad 114$

Decompensatio cordis

$\begin{array}{ccccc}\text { No } & 591 & 466 & 78.9 & 84.8 \\ \text { Yes } & 30 & 24 & 80 & 78.7 \\ \text { COPD } & & & & \\ \text { No } & 591 & 454 & 78.41 & 84.9 \\ \text { Yes } & 42 & 36 & 80 & 782\end{array}$

\section{Charlson comorbidity index}

$\begin{array}{ll}0 & 336 \\ 1+ & 283\end{array}$

\section{ASA score}

$$
\begin{array}{ll}
\text { I + II } & 526 \\
\text { III + IV } & 92
\end{array}
$$

CEA

$$
\begin{array}{ll}
<7 \mathrm{ug} / \mathrm{L} & 430 \\
\geq 7 \mathrm{ug} / \mathrm{L} & 146
\end{array}
$$

Tumor location

$$
\begin{array}{ll}
\text { Colon } & 444 \\
\text { Rectum } & 177
\end{array}
$$

$\begin{array}{lll}256 & 76.4 & 82 \\ 234 & 81.8 & 83.7\end{array}$

280

82.4

88.5

210

74.7

80.1

\section{5}

289

211

196

83.1

79.7

82.8

\begin{tabular}{|c|c|c|c|c|}
\hline & $\begin{array}{l}\text { Total NED, DOD, } \\
\text { AWD }(N=621)\end{array}$ & $\begin{array}{l}\text { Observed } \\
5 \text {-year } \\
\text { survivors }\end{array}$ & $\begin{array}{l}\% \\
\text { observed }\end{array}$ & $\begin{array}{l}\text { Predicted } \\
\text { cure }\end{array}$ \\
\hline \multicolumn{5}{|l|}{ T-stage } \\
\hline 1 & 36 & 34 & 94.4 & 92.2 \\
\hline 2 & 193 & 171 & 88.6 & 92.1 \\
\hline 3 & 362 & 270 & 74.6 & 81.2 \\
\hline 4 & 30 & 15 & 50 & 62.3 \\
\hline \multicolumn{5}{|l|}{$\mathrm{N}$-stage } \\
\hline 0 & 336 & 303 & 90.2 & 92.7 \\
\hline 1 & 134 & 103 & 76.9 & 82.9 \\
\hline 2 & 80 & 33 & 41.3 & 50.1 \\
\hline$x$ & 71 & 51 & 71.8 & 83.4 \\
\hline \multicolumn{5}{|l|}{ Tumor stage } \\
\hline 1 & 180 & 164 & 91.1 & 94.6 \\
\hline$\|$ & 227 & 190 & 83.7 & 88.4 \\
\hline III & 214 & 136 & 63.6 & 71 \\
\hline \multicolumn{5}{|c|}{ Tumor grade } \\
\hline Good & 79 & 66 & 83.5 & 86.5 \\
\hline Moderate & 470 & 377 & 80.2 & 85.7 \\
\hline Poor & 53 & 33 & 62.3 & 73.1 \\
\hline $\begin{array}{l}\text { Unknown/ } \\
\text { other }\end{array}$ & 10 & 7 & 70 & 79.7 \\
\hline \multicolumn{5}{|l|}{ Radicality } \\
\hline RO & 605 & 477 & 80 & 84.5 \\
\hline R1 & 15 & 12 & 78.8 & 77.5 \\
\hline \multicolumn{5}{|c|}{ Postoperative complications } \\
\hline No & 266 & 298 & 83.9 & 90.4 \\
\hline Yes & 355 & 192 & 72.2 & 76.8 \\
\hline \multicolumn{5}{|c|}{ Readmission $<30$ days } \\
\hline No & 552 & 438 & 79.5 & 94.1 \\
\hline Yes & 68 & 52 & 76.5 & 87.1 \\
\hline \multicolumn{5}{|c|}{ Neoadjuvant therapy } \\
\hline No & 462 & 383 & 82.9 & 85.7 \\
\hline Yes & 158 & 106 & 67.1 & 79.9 \\
\hline \multicolumn{5}{|c|}{ Adjuvant chemotherapy } \\
\hline No & 127 & 382 & 78.1 & 84 \\
\hline Yes & 489 & 104 & 81.9 & 86.1 \\
\hline
\end{tabular}

Table 2 Characteristics of patients with potential cure and probability of cure estimated from the semiparametric mixture cure model (Continued)

lower survival rate $(62 \%)$ and predicted cure $(73 \%)$ than were well-differentiated tumors $(83 \%$ and $87 \%$ respectively). These results highlight the importance of especially $\mathrm{T}$ - and $\mathrm{N}$-staging in non-metastatic CRC, seeing that current treatment strategies that have a curative intent are insufficient for a subgroup of patients 


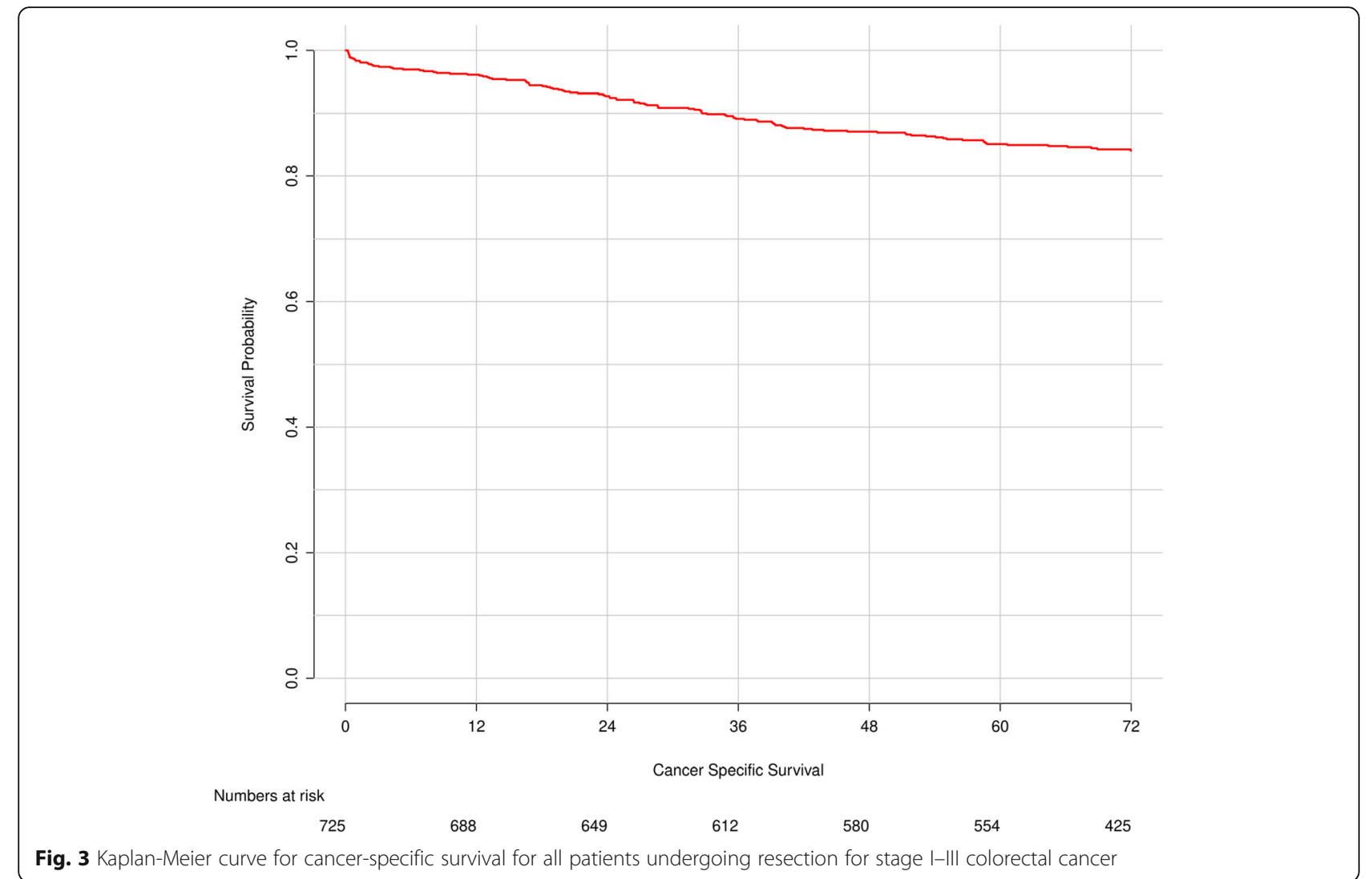

with poor tumor characteristics. Some studies have found encouraging survival outcomes in patients with a T4-tumor with the use of proactive strategies, such as the second-look approach $[26,27]$ and prophylactic resection of target organs for peritoneal metastases during the first surgery [28]. However, two large phase III trials failed to show benefit from adjuvant intraperitoneal hyperthermic chemoperfusion (HIPEC) in high-risk patients [29, 30]. An effective treatment for high-risk patients is therefore still needed.

The present study findings complement earlier results in in that they associate older age with poorer cancer-specific survival [31,32]. Provision of less intensive therapy to the elderly or the elderly refusing treatment may have resulted in higher recurrence rates and causal death [33-36].

In line with previous literature, patients with rectal cancer had significantly lower chances of long-term survival and cure than had patients with colon cancer [37]. Sex, for which literature shows contradicting results, was not a prognostic factor for survival [38-42]. Furthermore, we found no association between the presence of comorbidities and CSS. Diabetes, congestive heart failure, and COPD, but also grading systems for comorbidities such as the ASA score and the CCI index, were not associated with CSS in our study. The literature on the association between comorbidities and CSS is somewhat contradictory. While some studies found a lower survival with increasing comorbidity, other studies found the association differs between colon cancer and rectal cancer $[43,44]$. The reasons underlying these results in other studies have not been elucidated, although possible contributors include under-treatment and reduced resilience to cope with cancer effects and treatment toxicity.

This is, to our knowledge, the first study to provide unique estimates of the likelihood of both observed and predicted cure depending on particular risk factors in a large Dutch prospective multicenter study on stage I-III colorectal cancer patients.

However, this study has several limitations. In general, surveillance imaging had been performed at least every 6 months after surgery. The time interval of 6 months may have led to lead time bias. As mentioned in the results, for 85 patients with an N0 tumor, less than 10 lymph nodes were dissected or pathologically analyzed which could have led to wrong nodal staging. This could inherently lead to survival differences if some of these patients did actually have lymph node metastases. Furthermore, we did not address molecular tumor characteristics that are related to survival, which play an increasingly bigger role in the prediction of survival in CRC [45]. 
In conclusion, while CRC is recognized as a possible fatal malignancy, a substantial improvement on therapies and thereby survival of patients with CRC has been accomplished over the recent years. Appropriate survival analysis like the mixture cure rate model performed in this study can help the clinicians and researchers in identifying potential risk factors, which affect the survival and cure fraction of patients who are not susceptible to death from CRC. This mixture cure model provides a framework to compare both patient-related and treatment-related prognostic factors and to gives valuable insight in the probability of being cured of CRC for each of these variables. The probability of cure for patients with stage I-III colorectal cancer included in this study ranges from 50 to $94 \%$. Even with poor prognostic factors, such as high tumor stage and poor differentiation grade, cure is highly likely with standard therapy consisting of surgery and adjuvant or neoadjuvant systemic therapy when indicated. Still, this is less obvious for older patients with high $\mathrm{T}$ - and $\mathrm{N}$-stage tumors and/or poor tumor differentiation. Instead of only providing patients with overall 5-year survival rates, with general patient characteristics, this cure model can aid physicians in providing a more individualized prognosis and chance of curation from this disease.

\section{Authors' contributions}

Conceived and/or designed the work that led to the submission, acquired data, and/or played an important role in interpreting the results: I. van den Berg, R.R.J. Coebergh van den Braak, J.L.A. van Vugt, J.N.M. IJzermans, S. Buettner. Drafting or revised the manuscript: I. van den Berg, R.R.J. Coebergh van den Braak, J.L.A. van Vugt, J.N.M. IJzermans, S. Buettner. Approved the final version: I. van den Berg, R.R.J. Coebergh van den Braak, J.L.A. van Vugt, J.N.M. IJzermans, S. Buettner. Agreement to be accountable for all aspects of the work in ensuring that questions related to the accuracy or integrity of any part of the work are appropriately investigated and resolved: I. van den Berg, R.R.J. Coebergh van den Braak, J.L.A. van Vugt, J.N.M. IJzermans, S. Buettner.

\section{Funding}

Not applicable.

\section{Availability of data and materials}

The data that support the findings of this study are available on request from the corresponding author. The data are not publicly available due to privacy or ethical restrictions.

\section{Declarations}

\section{Ethics approval and consent to participate}

The MATCH study was approved by the Erasmus MC medical ethics review board (MEC-2007-088), and all patients provided written informed consent to use their data.

\section{Consent for publication}

Not applicable.

\section{Competing interests}

The authors declare no potential conflicts of interest.
Received: 4 January 2021 Accepted: 19 March 2021

Published online: 05 April 2021

\section{References}

1. The Global Cancer Observatory (GCO). https://gco.iarc.fr/. Accessed Aug 2020.

2. Dienstmann R, Mason MJ, Sinicrope FA, Phipps Al, Tejpar S, Nesbakken A, et al. Prediction of overall survival in stage II and III colon cancer beyond TNM system: a retrospective, pooled biomarker study. Ann Oncol. 2017; 28(5):1023-31. https://doi.org/10.1093/annonc/mdx052.

3. Karahalios A, English DR, Simpson JA. Weight change and risk of colorectal cancer: a systematic review and meta-analysis. Am J Epidemiol. 2015; 181(11):832-45. https://doi.org/10.1093/aje/kwu357.

4. Lauby-Secretan B, Scoccianti C, Loomis D, Grosse Y, Bianchini F, Straif K, et al. Body fatness and cancer--viewpoint of the IARC Working Group. N Engl J Med. 2016;375(8):794-8. https://doi.org/10.1056/NEJMsr1606602.

5. Yuhara H, Steinmaus C, Cohen SE, Corley DA, Tei Y, Buffler PA. Is diabetes mellitus an independent risk factor for colon cancer and rectal cancer? Am J Gastroenterol. 2011;106(11):1911-21; quiz 1922. https://doi.org/10.1038/a jg.2011.301.

6. Longo WE, Johnson FE. The preoperative assessment and postoperative surveillance of patients with colon and rectal cancer. Surg Clin North Am. 2002;82(5):1091-108. https://doi.org/10.1016/S0039-6109(02)00050-6.

7. Society AC. Cancer facts \& figures 2020. Am Cancer Soc J CA. 2020. p. 3.

8. Rondeau V, Schaffner E, Corbiere F, Gonzalez JR, Mathoulin-Pelissier S. Cure frailty models for survival data: application to recurrences for breast cancer and to hospital readmissions for colorectal cancer. Stat Methods Med Res. 2013;22(3):243-60. https://doi.org/10.1177/0962280210395521.

9. Lambert PC, Thompson JR, Weston CL, Dickman PW. Estimating and modeling the cure fraction in population-based cancer survival analysis. Biostatistics. 2007;8(3):576-94. https://doi.org/10.1093/biostatistics/kxl030.

10. Primrose JN, Perera R, Gray A, Rose P, Fuller A, Corkhill A, et al. Effect of 3 to 5 years of scheduled CEA and CT follow-up to detect recurrence of colorectal cancer: the FACS randomized clinical trial. JAMA. 2014;311(3):26370. https://doi.org/10.1001/jama.2013.285718.

11. Wille-Jørgensen P, Syk I, Smedh K, Laurberg S, Nielsen DT, Petersen SH, et al Effect of more vs less frequent follow-up testing on overall and colorectal cancer-specific mortality in patients with stage II or III colorectal cancer: the COLOFOL randomized clinical trial. JAMA. 2018;319(20):2095-103. https:// doi.org/10.1001/jama.2018.5623.

12. Dutch Cancer Institute. Colorectal cancer guideline. 2017.

13. Yu Y, Carey M, Pollett W, Green J, Dicks E, Parfrey P, et al. The longterm survival characteristics of a cohort of colorectal cancer patients and baseline variables associated with survival outcomes with or without time-varying effects. BMC Med. 2019;17(1):150. https://doi.org/1 0.1186/s12916-019-1379-5

14. Bouvier A-M, Launoy G, Bouvier V, Rollot F, Manfredi S, Faivre J, et al. Incidence and patterns of late recurrences in colon cancer patients. Int J Cancer. 2015;137(9):2133-8. https://doi.org/10.1002/ijc.29578.

15. Lalmahomed ZS, Coebergh van den Braak RRJ, Oomen MHA, Arshad SP, Riegman PHJ, IJzermans JN, et al. Multicenter fresh frozen tissue sampling in colorectal cancer: does the quality meet the standards for state of the art biomarker research? Cell Tissue Bank. 2017;18(3):425-31. https://doi.org/10.1 007/s10561-017-9613-x.

16. Kloosterman WP, Coebergh van den Braak RRJ, Pieterse $M$, van Roosmalen MJ, Sieuwerts AM, Stangl C, et al. A systematic analysis of oncogenic gene fusions in primary colon cancer. Cancer Res. 2017;77(14):3814-22. https:// doi.org/10.1158/0008-5472.CAN-16-3563.

17. Creasy JM, Sadot E, Koerkamp BG, Chou JF, Gonen M, Kemeny NE, et al. Actual 10-year survival after hepatic resection of colorectal liver metastases: what factors preclude cure? Surgery. 2018;163(6):1238-44. https://doi.org/1 0.1016/.j.surg.2018.01.004.

18. van Vugt JLA, Buettner S, Levolger S, Coebergh van den Braak RRJ, Suker M, Gaspersz MP, et al. Low skeletal muscle mass is associated with increased hospital expenditure in patients undergoing cancer surgery of the alimentary tract. PLoS One. 2017;12(10):e0186547. https://doi.org/10.1371/ journal.pone.0186547.

19. Othus M, Barlogie B, Leblanc ML, Crowley JJ. Cure models as a useful statistical tool for analyzing survival. Clin Cancer Res. 2012:18(14):3731-6. https://doi.org/10.1158/1078-0432.CCR-11-2859. 
20. Yilmaz YE, Lawless JF, Andrulis IL, Bull SB. Insights from mixture cure modeling of molecular markers for prognosis in breast cancer. J Clin Oncol. 2013;31(16):2047-54. https://doi.org/10.1200/JCO.2012.46.6615.

21. Sy JP, Taylor JM. Estimation in a Cox proportional hazards cure model. Biometrics. 2000;56(1):227-36. https://doi.org/10.1111/j.0006-341X.2000.0022 7.x.

22. Chao Cai YZ, Peng Y, Zhang J. Fit semiparametric mixture cure models. In: An R-package for estimating semiparametric PH and AFT mixture cure models, vol. 2.0; 2012.

23. Gunderson LL, Jessup JM, Sargent DJ, Greene FL, Stewart AK. Revised TN categorization for colon cancer based on national survival outcomes data. J Clin Oncol. 2010;28(2):264-71. https://doi.org/10.1200/JCO.2009.24.0952.

24. Blenkinsopp WK, Stewart-Brown S, Blesovsky L, Kearney G, Fielding LP. Histopathology reporting in large bowel cancer. J Clin Pathol. 1981;34(5): 509-13. https://doi.org/10.1136/jcp.34.5.509.

25. Schneider NI, Langner C. Prognostic stratification of colorectal cancer patients: current perspectives. Cancer Manag Res. 2014;6:291-300. https:// doi.org/10.2147/CMAR.S38827.

26. Serrano Del Moral A, Perez Viejo E, Manzanedo Romero I, Rodriguez Caravaca G, Pereira Perez F. Systematic second-look surgery plus HIPEC in patients without evidence of recurrence, at high risk of carcinomatosis after colorectal cancer resection. Cir Esp. 2018;96(2):96-101. https://doi.org/10.101 6/j.ciresp.2017.11.006.

27. Elias D, Honoré C, Dumont F, Ducreux M, Boige V, Malka D, et al. Results of systematic second-look surgery plus hipec in asymptomatic patients presenting a high risk of developing colorectal peritoneal carcinomatosis. Ann Surg. 2011;254(2):289-93. https://doi.org/10.1097/SLA.0b013e3182263 $8 f 6$.

28. Sammartino P, Sibio S, Biacchi D, Cardi M, Mingazzini P, Rosati MS, et al. Long-term results after proactive management for locoregional control in patients with colonic cancer at high risk of peritoneal metastases. Int J Colorectal Dis. 2014;29(9):1081-9. https://doi.org/10.1007/s00384-014-1929-4.

29. Moran BJ. PROPHYLOCHIP: no benefit of second-look surgery plus HIPEC for colorectal peritoneal metastases. Lancet Oncol. 2020;21(9):1124-5. https:// doi.org/10.1016/S1470-2045(20)30338-7.

30. Klaver CEL, Wisselink DD, Punt CJA, Snaebjornsson P, Crezee J, Aalbers A, et al. Adjuvant HIPEC in patients with colon cancer at high risk of peritoneal metastases: Primary outcome of the COLOPEC multicenter randomized trial. J Clin Oncol. 2019;37:482.

31. Baghestani AR, Daneshva T, Pourhoseingholi MA, Asadzadeh $H$. Survival of colorectal cancer in the presence of competing- risks - modeling by Weibull Distribution. Asian Pac J Cancer Prev. 2016;17(3):1193-6. https://doi.org/10. 7314/APJCP.2016.17.3.1193

32. Morrison DS, Parr CL, Lam TH, Ueshima H, Kim HC, Jee SH, et al. Behavioural and metabolic risk factors for mortality from colon and rectum cancer: analysis of data from the Asia-Pacific Cohort Studies Collaboration. Asian Pac J Cancer Prev. 2013;14(2):1083-7. https://doi.org/10.7314/APJCP.2 013.14.2.1083.

33. Cree M, Tonita J, Turner D, Nugent Z, Alvi R, Barss R, et al. Comparison of treatment received versus long-standing guidelines for stage III colon and stage II/III rectal cancer patients diagnosed in Alberta, Saskatchewan, and Manitoba in 2004. Clin Colorectal Cancer. 2009;8(3):141-5. https://doi.org/1 0.3816/CCC.2009.n.023.

34. Winget $M$, Hossain $S$, Yasui $Y$, Scarfe A. Characteristics of patients with stage III colon adenocarcinoma who fail to receive guideline-recommended treatment. Cancer. 2010;116(20):4849-56. https://doi.org/10.1002/cncr.25250.

35. Lemmens VE, van Halteren $\mathrm{AH}$, Janssen-Heijnen ML, Vreugdenhil G, Repelaer van Driel OJ, Coebergh JW. Adjuvant treatment for elderly patients with stage III colon cancer in the southern Netherlands is affected by socioeconomic status, gender, and comorbidity. Ann Oncol. 2005;16(5):76772. https://doi.org/10.1093/annonc/mdi159.

36. Quipourt V, Jooste V, Cottet V, Faivre J, Bouvier AM. Comorbidities alone do not explain the undertreatment of colorectal cancer in older adults: a French population-based study. J Am Geriatr Soc. 2011;59(4):694-8. https:// doi.org/10.1111/j.1532-5415.2011.03334.x.

37. van Erning FN, van Steenbergen LN, Lemmens $V$, Rutten HJT, Martijn $H$, van Spronsen DJ, et al. Conditional survival for long-term colorectal cancer survivors in the Netherlands: who do best? Eur J Cancer. 2014;50(10):1731-9. https://doi.org/10.1016/j.ejca.2014.04.009.

38. Azizmohammad Looha M, Pourhoseingholi MA, Nasserinejad M, Najafimehr $H$, Zali MR. Application of a non-parametric non-mixture cure rate model for analyzing the survival of patients with colorectal cancer in Iran. Epidemiol Health. 2018;40:e2018045. https://doi.org/10.4178/epih.e2018045.

39. Paulson EC, Wirtalla C, Armstrong K, Mahmoud NN. Gender influences treatment and survival in colorectal cancer surgery. Dis Colon Rectum. 2009; 52(12):1982-91. https://doi.org/10.1007/DCR.0b013e3181 beb42a.

40. McArdle CS, McMillan DC, Hole DJ. Male gender adversely affects survival following surgery for colorectal cancer. Br J Surg. 2003;90(6):711-5. https:// doi.org/10.1002/bjs.4098.

41. Majek O, Gondos A, Jansen L, Emrich K, Holleczek B, Katalinic A, et al. Sex differences in colorectal cancer survival: population-based analysis of 164,996 colorectal cancer patients in Germany. PLoS One. 2013;8(7):e68077. https://doi.org/10.1371/journal.pone.0068077.

42. Micheli A, Ciampichini R, Oberaigner W, Ciccolallo L, de Vries E, Izarzugaza I, et al. The advantage of women in cancer survival: an analysis of EUROCARE4 data. Eur J Cancer. 2009;45(6):1017-27. https://doi.org/10.1016/j.ejca.2 008.11 .008 .

43. van Eeghen EE, Bakker SD, van Bochove A, Loffeld RJ. Impact of age and comorbidity on survival in colorectal cancer. J Gastrointest Oncol. 2015;6(6): 605-12. https://doi.org/10.3978/j.issn.2078-6891.2015.070.

44. Pule ML, Buckley E, Niyonsenga T, Roder D. The effects of comorbidity on colorectal cancer mortality in an Australian cancer population. Sci Rep. 2019; 9(1):8580. https://doi.org/10.1038/s41598-019-44969-8.

45. Guinney J, Dienstmann R, Wang X, de Reynies A, Schlicker A, Soneson C, et al. The consensus molecular subtypes of colorectal cancer. Nat Med. 2015;21(11):1350-6. https://doi.org/10.1038/nm.3967.

\section{Publisher's Note}

Springer Nature remains neutral with regard to jurisdictional claims in published maps and institutional affiliations.
Ready to submit your research? Choose BMC and benefit from:

- fast, convenient online submission

- thorough peer review by experienced researchers in your field

- rapid publication on acceptance

- support for research data, including large and complex data types

- gold Open Access which fosters wider collaboration and increased citations

- maximum visibility for your research: over $100 \mathrm{M}$ website views per year

At BMC, research is always in progress.

Learn more biomedcentral.com/submissions 